\title{
微細な地形標高を考慮した都市型中小河川 の氾濫数值計算 \\ NUMERICAL SIMULATION FOR INUNDATION FLOW AROUND A SMALL- TO MEDIUM SIZED RIVER WITH FINE INFORMATION OF ALTITUDE
}

\author{
細山田得三 1 早川典生 $2 \cdot$ 加納裕美 3 ・酒井彩美 3 \\ 1正会員 工博 長岡技術科学大学 環境・建設系 助教授 ( $\mp 940-2188$ 長岡市上富岡1603-1) \\ 2正会員 Ph. D長岡技術科学大学 環境・建設系 教授 \\ 3 学生会員 長岡技術科学大学大学院
}

\begin{abstract}
In this study, a numerical simulation of inundation flow in an urban area is carried out using fine information of altitude. The numerical model is two-dimensional shallow water model. The grid size is $1 \mathrm{~m}$, which is fine enough to understand overland flow in an urban area. The altitude data is obtained by altitude of lid of manhole distributed randomly in the study area. The resolution of the altitude data is $1 \mathrm{~cm}$, which is fine enough to represent the contrast of altitude in a flat urban area. The numerical results proved that the inundation flow is sensitively affected by the geophysical features with undulation in the area.
\end{abstract}

Key Words : inundation flow model, urban area, information of altitude, small to medium sized river

\section{1.はじめに}

都市の中心部近くを流れる中小河川は都市における 早い降雨流出を処理する目的で自治体を主体として整 備されることになっている。しかしながら、そのよう な中小都市河川の周辺では既に土地利用や都市化が十 分進んでおり、河川改修工事が困難であるため整備計 画の達成率が低いものが多い。このため夏季の集中豪 雨時に河川の近隣周辺が汇濫の危険にさらされている。 このような状況では、河川改修によるハード面での対 策の高度化だけでは不十分であり、日ごろから洪水災 害に対する住民の防災意識の涵養などソフト面の対策 も重要である。本学、長岡技術科学大学が位置する長 岡市の中心部を流れる柿川周辺も写真-1（上段）に示 すようにそのような都市河川の特徽を有している。長 岡市は過去 30 年間で規模の大きな洪水災害は 5 回程度 発生しており（写真 1 下段 : 長岡市土木部下水道管理 課）、そのうち規模の小さいものは時間雨量 $16 \mathrm{~mm}, 1$ 日 雨量 $200 \mathrm{~mm}$ となっており、時間雨量にして毎年、 1 日雨 量にして 10 年に一度の規模である。将来においても数 年に一度は洪水の危険性があり、しかも1998年に新潟 市を見舞った大雨（1時間雨量 $96 \mathrm{~mm}$ ) が発生する危険性
を否定できない。

このような洪水による災害に対して行政としては洪 水氾監シミュレーション結果をハザードマップとして 公開するなどの対策を行っている。このハザードマッ プは国土交通省（旧建設省）の管理する大規模な一級 河川を対象としている場合が多く、自治体が管理する 都市域の中小河川を対象としたものは少ない。都市域 の中小河川は川幅が10m未満のものもあり、ハザード マップの数百mの解像度では評価することが困難である。

洪水汇濫の数值計算の空間的な解像度を上げる上で 2 つの問題点が挙げられる。それらは、計算容量の増 大や時間刻みを小さくする必要があるためにCPU時間が 増大するなどの計算機能力上の問題と空間解像度を上 げることに見合うほどに標高データや土地利用情報の 高解像度化を行なう必要があるという問題である。前 者の問題は近年の計算機能力の目覚しい向上とその発 展の持続により解消されていくものと思われる. それ に比して後者の問題は現在提供されているデジタル標 高データモデル:DEM(Digital Elevation Model)の解像 度 (空間 $50 \mathrm{~m}$ 、標高精度 $1 \mathrm{~m}$ ) では都市域での微小な地形 勾配を表現することは困難である。事実、そのDEMに よって地形標高の等高線を描いてみると、都市域は殆 ど平地としてしか表現されない。一方，建設工事等に 


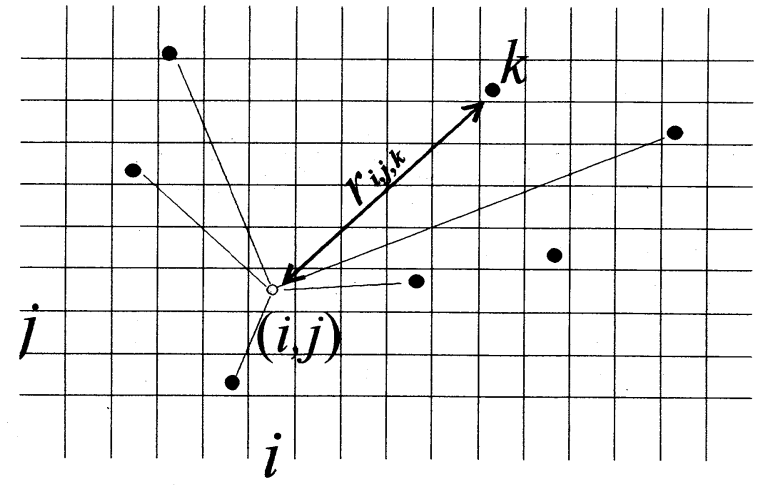

図-1＼cjkstart格子点 $(i, j)$ とマンホール標高の計測点 $(k)$

図中はは任意に点在するマンホールの配置を示す。

おいては地形標高を必ず計測していると推測され、地 形標高データが必ず何らかの形で保存管理されている と考えられる。本研究ではそれらの一例である長岡市 土木部下水道管理課に执いて管理されている長岡小圭 域に設置されたマンホール蓋数万点の標高值を利用す ることにした。このデータの標高の分解能が $1 \mathrm{~cm}$ であ り、十分な解像度である。対象河川は先に述べた長岡 市の中心を流れる柿川の一部とし、対象領域を定め、 マンホール蓋の標高を利用して詳細なDEMデータを作成 した。そして長岡市中心部を流れる柿川の一部を対象 としてマンホール標高データから柿川を含む長岡市中 心部のDEMを作成し、格子間隔 $1 \mathrm{~m}$ で洪水氾濫計算を 行った。柿川の諸元は、表-1にまとめて示す。

\section{DEMの作成}

DEMの作成は長岡市内のマンホール標高データのうち、 柿川の一部を含んだ長岡市中心部殿町の東西 $1.0 \mathrm{~km}$ 南北

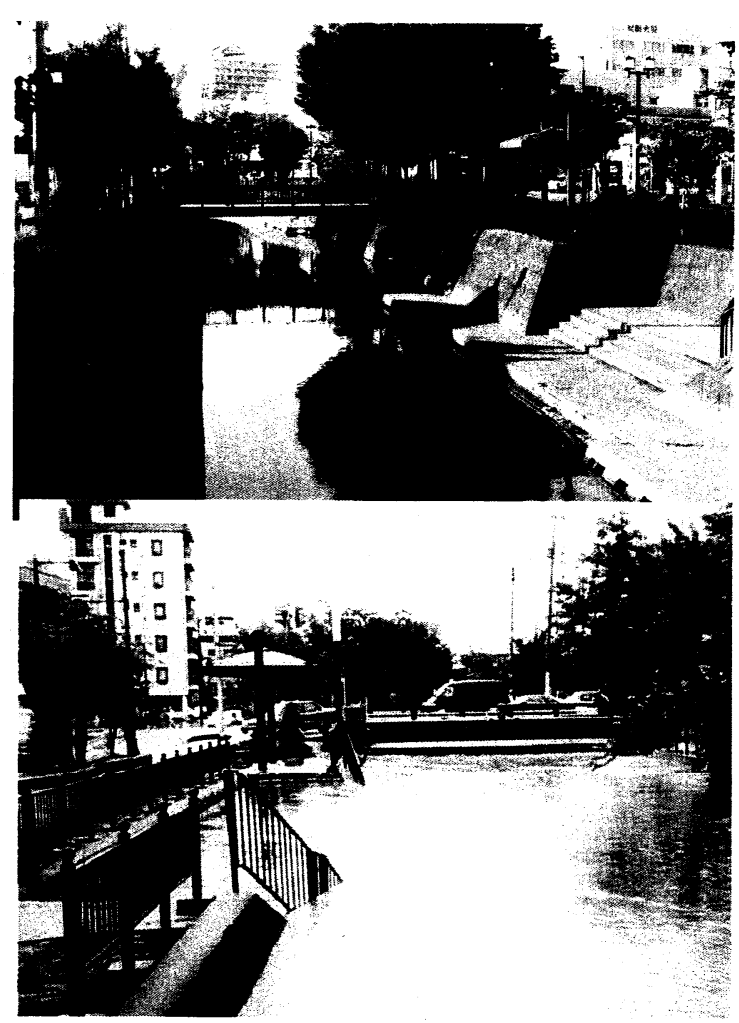

写真-1，長岡市中心部を流れる柿川

上: 平水時、下: 洪水時 撮影地点は図-2を参照

表-1＼cjkstart長岡市柿川の諸元

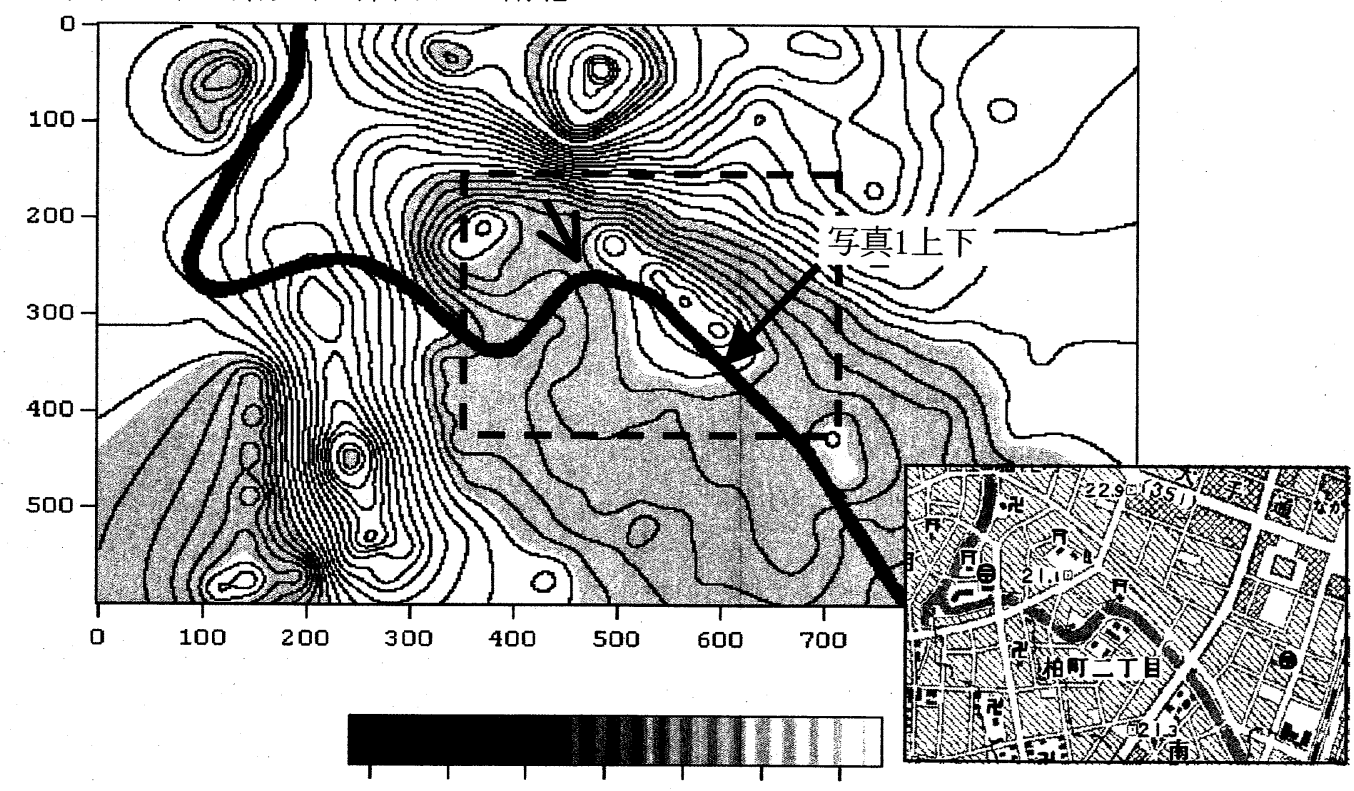

$18.519 .019 .520 .020 .521 .021 .5 \mathrm{~m}$

図-2. 長岡市中心部のDEMおよび長岡市中心部の地図画像 縦軸および横軸の数字は格子点数を示す。 
0.6kmの範囲を対象とした。この範囲には400点を越す マンホール蓋があり、標高データが地図上に示されて いる。このように空間上に任意に分布した標高の情報 が得られている場合のDEMの作成プログラムは、最近の GISソフトなどには標準的に装備されていることが多い が、そのアルゴリズムについては公開されていないり。 また、今回、DEMを作成するために前もって準備した データは平面上に任意にばらついているため、一般的 に用いられている等高線のベクターデータから格子点 上の標高データを作成するプログラムのアルゴリズム は用いることができないと考えられる。このため、今 回は以下のような手順によってDEMを作成した。図-1に はその手法の概略を説明するための模式図を示してい

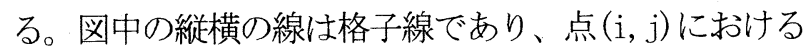
標高值を未知、黒丸で示した位置でのマンホール(通し 番号k)の標高が既知とした場合を考えている。まず、 地図をスキャナで読み込み、該当範囲内にあるマン ホール $(k)$ の水平座標と標高值 $\left(d_{k}\right)$ を読み取り、ファイ ルに保存する。この後、標高值が未知である平面2次元 上の格子点 $(i, j)$ とマンホール $(k)$ との水平距離 $r_{i, k}$ を求め、 距離の逆数に関係した重み関数を定義する。今回実際 にDEMを作成するために用いた重み関数を式(1)に示す。

$$
w_{i, j, k}=1.0-\exp \left(-50 / r_{i, j, k}\right)
$$

2 点の距離である $r_{i, j}$ が十分小さいところでは重み関数 が最大值 1 に近い值をとり、 $r_{i, j}$ が例えば50mの場合は、 重み関数が 0.632 となる。距離の逆数に関係した重み関 数の形に関する一般的な指標を与えることはできず、 実際にDEMを作成してその結果を見て採用するか否かを 決定するしか方法はない。式（1）の中に示されている パラメータの值である $50 \mathrm{~m}$ も結果を見て採用を決めた ものである。この重み関数を用いて式(2)に示した重み 付き平均をとり、格子点 $(i, j)$ の標高値 $d i, j$ が計算される。

$$
d_{i, j}=\frac{\sum_{k} w_{i, j, k} d_{k}}{\sum_{k} w_{i, j, k}}
$$

図-2にはこのようにして作成されたDEMおよびその右 下の領域にほぼ対応した数值地図2500（（財）地図セ ンター）を示す。長岡市の中心部を流れる柿川は中央 の黒く太い実線で表示されている。上流は図面の右下 で、柿川は図の中心付近で蛇行しながら左上方向に流 れており、この図より数キロメートル下流地点で信濃 川に注いでいる。格子上に計算された標高値の空間分 布をみると、矢印で示した、図の中心付近の蛇行部よ りも若干上流側でかなり低い標高となっており、また 矢印よりも北に向かって急激に標高值が高くなってい る。これらの結果は実際に踏查して目視した標高と矛 盾はないことを確認した。また、蛇行部よりもやや上 流側の地点において既往洪水が頻発している事が報告
されている。

DEMの作成と併せて、計算領域内の道路、住区、河道 の抽出を行い、計算格子の指標に用いた。

\section{3. 氾濫流の数値計算法}

\section{1 基礎方程式と離散化処理}

数值計算には氾濫流、河道内の流れともに平面 2 次 元で冠水域と没水域の区別を表現できる浅水方程式を 用いた。数值計算に用いた基礎方程式は、式(3)、式 (4)に示されている2),3), 4)。

$$
\begin{gathered}
\frac{\partial h}{\partial t}+\frac{\partial M_{i}}{\partial x_{i}}=0 \\
\frac{\partial M_{i}}{\partial t}+\frac{\partial}{\partial x_{j}}\left(\frac{M_{i} M_{j}}{h}\right) \\
=-g h \frac{\partial\left(z^{*}+h\right)}{\partial x_{i}}+A\left(\frac{\partial^{2} M_{i}}{\partial x_{m} \partial x_{m}}\right)-\frac{g n^{2}}{h^{1 / 3}} M_{i} \sqrt{M_{m} M_{m}}
\end{gathered}
$$

ここで式(3) は連続式、式(4) は平面2次元の $i$ 方向の非 線形長波方程式である。式 (2) 中のサフィックス $i=1, i=2$ はそれぞれ、東西方向と南北方向に対応する。 式中の記号、 $x_{i} 、 M_{1} 、 g 、 t 、 Z * 、 h 、 A 、 n$ はそれぞれ $i$ 方向水平座標、 $x_{i}$ 方向の線流量、重力加速度、時間、 DEMによる地盤高、水深、水平粘性係数、マニングの粗 度係数である。計算に用いた格子は直交矩形格子であ り、未知量 $M_{1} 、 h$ はスタガート格子を用いて平面格子内 のそれぞれ、右辺上、および中心点で定義されている。 式(3)，(4) に示寸基礎方程式の他に河道と周辺地盤高の ように水塊そのものが分離して計算せざるを得ない条 件も発生する。そのような場合には線流量qについて式 （5）に示寸越流公式を適用して計算を行った。

$$
q=0.35 h \sqrt{2 g h}
$$

時間積分には波の遡上の判別を各時間ステップで行 うため簡便な単純陽解法を用いた。このため時間間隔 を十分小さくとる必要があるが総計算時間が数時間で あり、大きな問題ではないと考えている。

DEMの作成と同時に地図を用いた土地利用の状況をデ ジタル化する作業を行ってそれを数值計算に利用した。 具体的には、柿川河道内部、建物、道路の3種類に分類 し、各格子点にその属性を割り当てる。例えば建物の 領域と判定された格子では、流速がゼロになるように 設定し、洪水の進入を止めるように設定した。これら の設定条件は現実の状況とはかなり異なるものであり、 今後さらに改良を加えていく必要がある。 


\section{2 引き波時に関する処理}

本計算における洪水汇濫の処理に関する概略の説明 を図-3に示す。各格子点が冠水域かそうでないかの領 域を指標として与え、冠水域と判断したら基礎方程式 を適用する。冠水域格子と陸域格子との境界線上では 両格子の平均水深を計算して線流量を計算した。この 方法によって洪水波の先端が陸域に対して進行してい くことができる。この点については従来提案されてい る方法と大差はないと考えられる。逆に洪水波が引い ていく場合では水面が陸上標高よりも低くなる場合が 発生する。この場合は、その格子での流出量と水の体 積との間に過不足が発生し、計算誤差となる。このこ とを避けるため、その格子に隣接した格子が冠水域か どうかを判別し、冠水域と判断された場合のみその方 向を向いた線流量に補正流量を付加した。補正流量は 陸上標高と誤差を含んだ水位との差に格子面積を乗じ て誤差体積とし、それがゼロとなるように線流量に補 正を加えた。

\section{3 計算条件}

計算の対象領域は、当初、図-2に示した領域全体と して1メートル四方の計算格子で計算を行っていたが 膨大な計算時間を要するため、今回はさらに図-2の中 心部に絞って計算を行った. 図-2の中央部近くの点線 は、実際に計算に用いた領域を示している。この領域

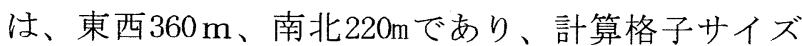
dx, dy はいずれも $1.0 \mathrm{~m}$ である。図-4には計算領域内
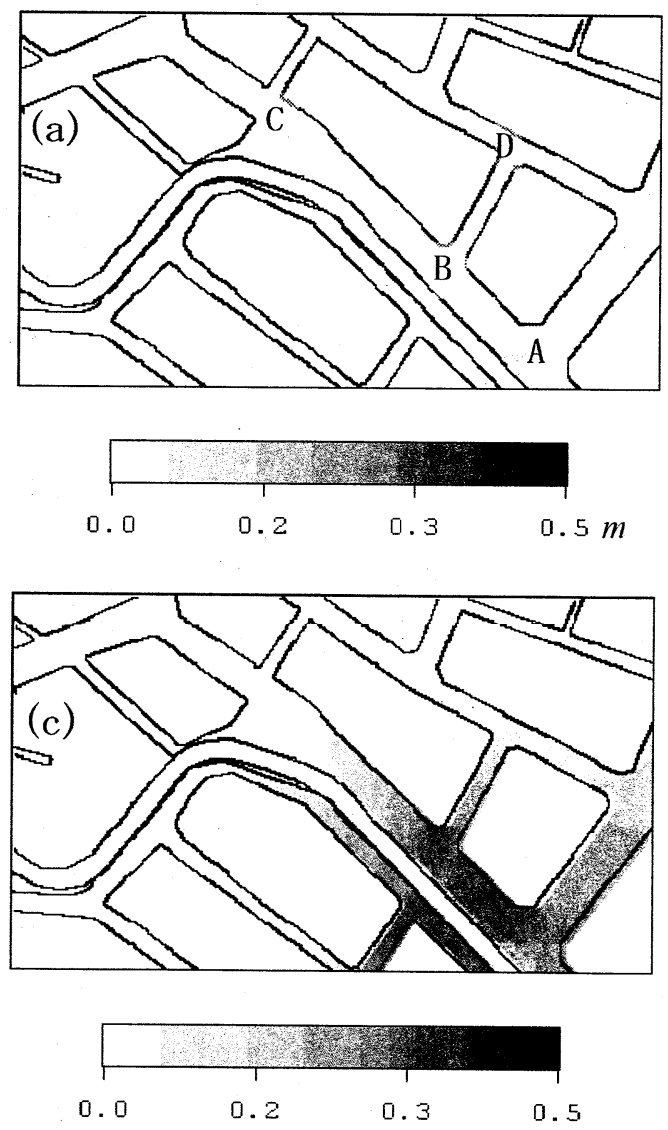
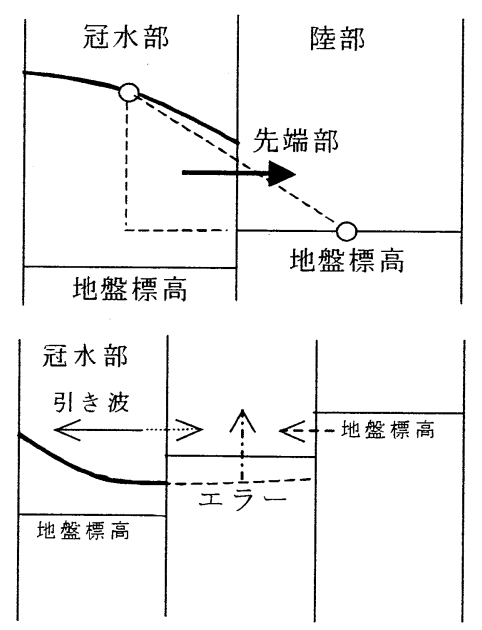

図-3＼cjkstart洪水汇濫の先端部および引き波の処理

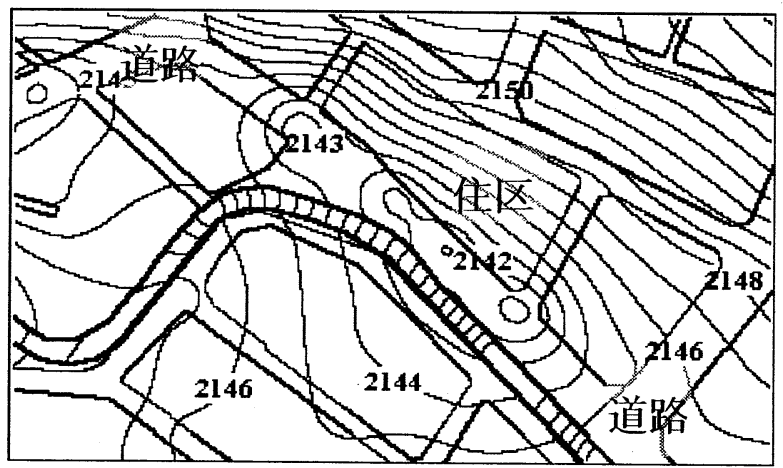

図-4計算に用いたDEMの等高線と 道路、建物、河道の区分け 単位cm
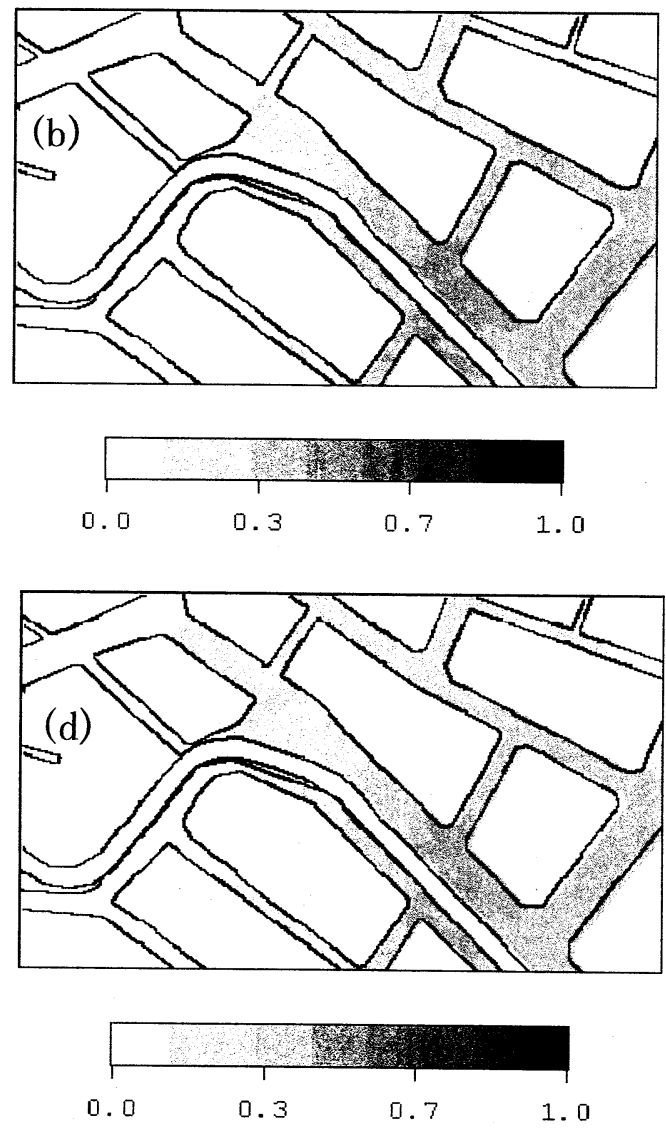

図-5 河道から市街地一進行する氾濫流の水位分布 (単位 $m$ ) 


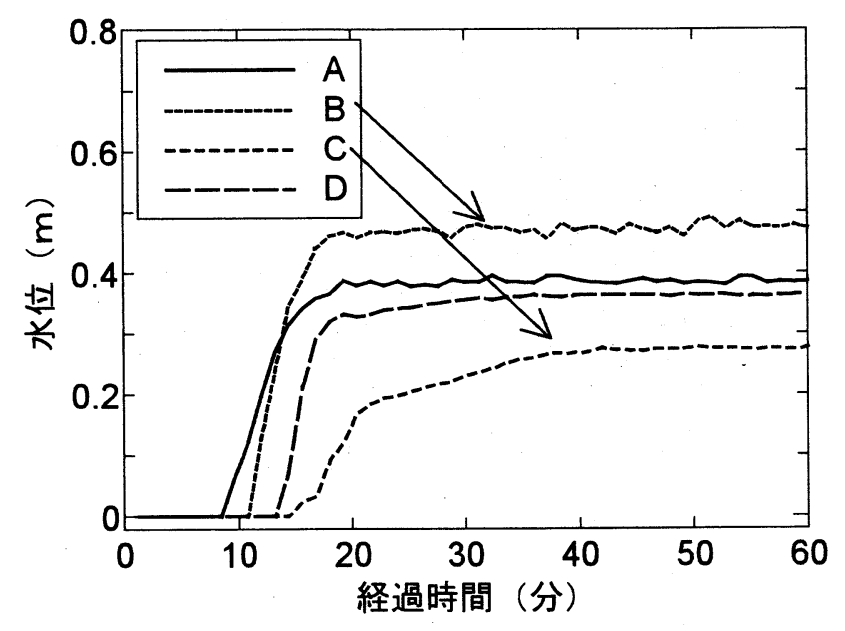

困-6 道路上の各点におけるハイドログラフ

の等高線と土地利用の区分けを併せて示している。こ の領域での柿川の河床標高は約19mであり、川幅は約 $20 \mathrm{~m}$ であ。

計算時間間隔dtは0.05sである。初期条件としては、 河道内部で $1.5 \mathrm{~m}$ の水深とし、それ以外の領域では水深 ゼロとした。計算領域の河道の上流端において洪水の 入射境界条件として水位変動を与えた。波形としては 振幅 $1.5 \mathrm{~m}$ の正弦波であるが、4分の 1 周期を超えた水 位が頂点に達したところで一定水位 $(3 \mathrm{~m})$ とした。図-7 には汇濫前の河道内の線流量ベクトルを示しており、 河道にそった安定した流れとなっている。

計算の境界条件としては、河川の洪水流の流入を上 流端（図-2右下部）で水位増加として与え、河川の流 出は下流端（図-2 左上部）で式(5) に示す越流境界と した。河川部以外の境界は流出なしという条件とした。 実際には境界外一流出させる必要があるが、今回の計 算では洪水が端部に到達する前に終了するため問題な いと考えている。

\section{4. 計算結果}

図-5，6には冠水域の時間的な広がりと領域内に示 したA, B. C.D点でのハイドログラフを示している。図5 の時間間隔は4.8分である。

図-5 (a)によれば、図中A点近くの柿川の右岸側から 汇濫が始まっていることがわかる。従来の洪水の氾濫 開始点よりもやや上流側に位置している。今回の計算 では正弦波によって洪水時の流量の増大を表現したが、 正弦波の周期が 3600 秒であり、実際よりも短かったこ とが原因ではないかと思われる。図-5 (b)〜 (d) では氾 濫流は、左岸よりも右岸側に多く発生しているが、こ れは長岡市土木部の職員への聞き取り調査と一致して いる。実際は河道の両岸に設置されたパラペットに よって左岸側への汇濫は計算よりも小さくなると思わ れる。右岸側の汇濫流は、道路に沿って進行している が、地形勾配に応じて汇濫の進行方向が変化している。 $\mathrm{A}$ 点からB点方向に向かう河道に平行な道路の方が、A点

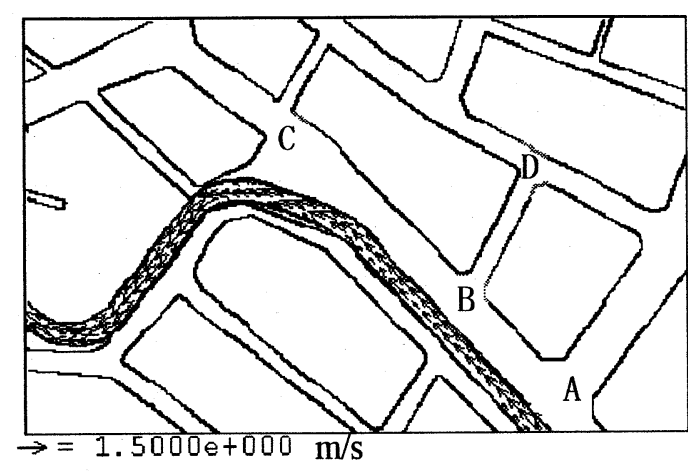

図-7 氾濫前の河道内の流れ(線流量)

から河道に直行している道路よりも汇濫流の進行が早 い。B点付近は図-4によると最も標高の低い領域であ り、氾濫流の挙動が標高に強い影響を受けていること が分かる。点故の水位は計算の全体を通して常に高い 值を保持している。図-6のハイドログラフによると汇 濫源に最も近いA点で水位は上昇し始めるが、B点での 水位もすぐに立ち上がり始め、数分で最も高い值と なってその後もその值を保持している。D点においては 汇濫源（A点付近）から遮蔽されているにもかかわらず 立ち上がりが比較的早く、水位も汇濫源とほぼ同じ程 度となっている。このことはD点への氾濫流の進入経路 が2つであったことと関係している。C点では氾濫源か ら直接的であり、遮蔽物は何もないにもかか扔らず、 氾濫水の浸入が遅く、立ち上がりも緩やかになってい る。これはC点の標高が若干高くなっていることと、B 点での汇濫水の滞留が汇濫流の進入を弱めているため である。

図-8には汇濫流の線流量ベクトルを示している。な お、柿川の河道内部の線流量ベクトルは汇濫流に比べ てかなり大きいため示していない。汇濫源のA点では、 はじめ早い線流量となっているが、A点からB点へ向か う間で道路に平行な方向にかなり強力な線流量が生じ ている。この領域以外では、D点付近でもある程度の強 い線流量となっている。C点付近では、あまり強い線流 量べクトルでけなく、C点に到详する前に河道へ戻る流 れも一部見られるようである。

\section{5. まとめ}

本研究では、マンホール標高データと住区データか ら柿川を含む長岡市中心部のDEMを作成し、都市型中小 河川の氾濫計算を行った。その結果、格子サイズが $1 \mathrm{~m}$ 程度の微細な地理情報を考慮した洪水氾濫シミュレー ションが可能であることが分かった。また、氾濫流の 空間的な分布特性が地形標高に鋭敏に影響されること が分かった。今回、計算の妥当性を比較する現場での 定量的なデータが得られていない。このことは今後の 

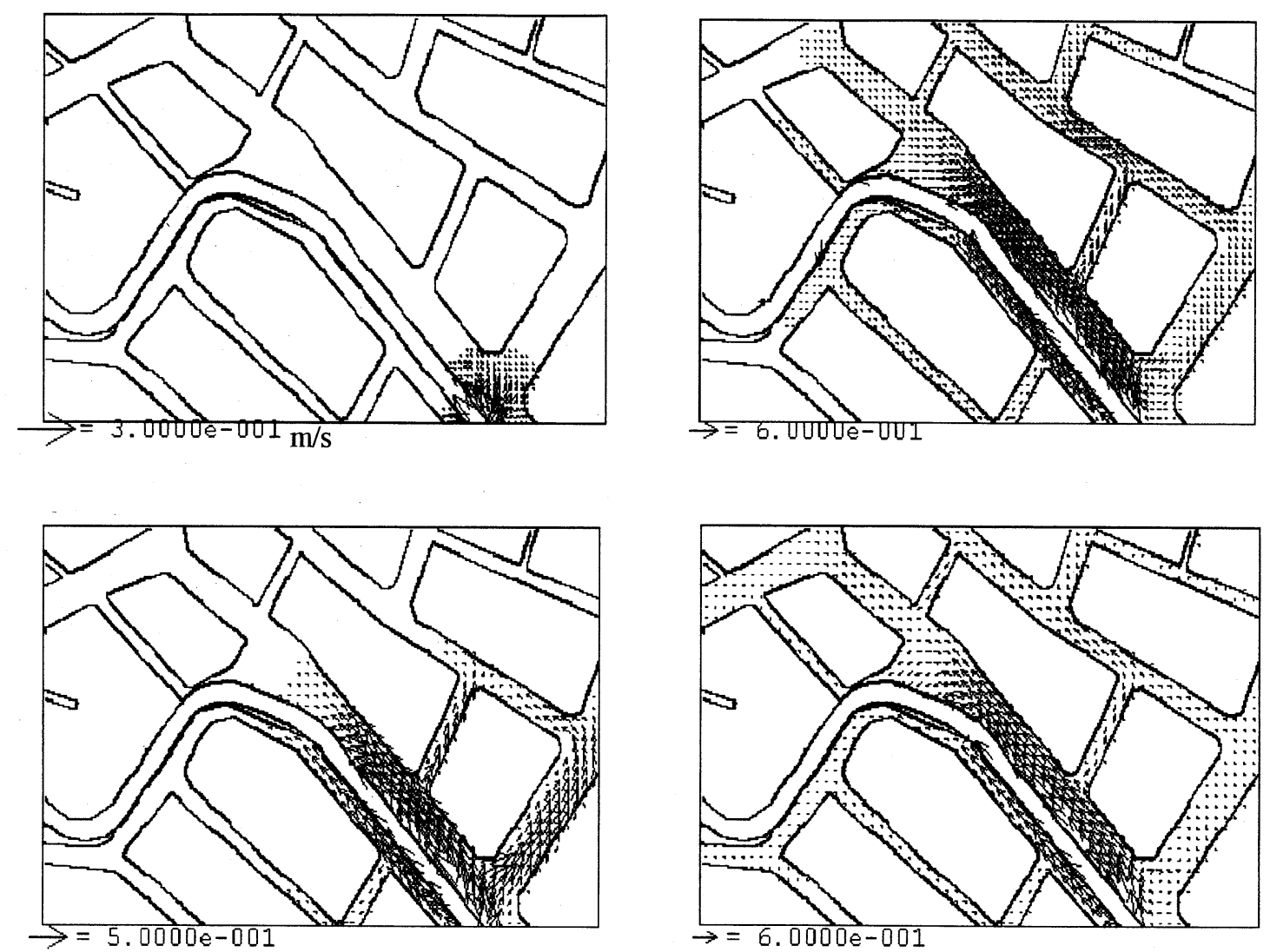

図-8 河道から市街地へ進行する氾濫流の流量べクトル

課題としたい。

洪水汇濫の数值計算のアルゴリズムに関しては従来、 多くの研究者が指摘しているように、汇濫流先端の移 動限界水深、運動方程式の移流項の処理、底面の摩擦 や水平方向の乱流粘性の影響など考慮すべき要因が数 多く含まれている。また、ダムブレークウェーブのよ うな非線形性がかなり強い現象を再現できるスキーム も各種提案されたり、非構造格子を用いたモデルの開

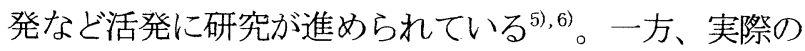
現象を表現するために家屋や下水道網などの地形情報 を詳細にモデルに反映させるための研究も進んでいる 7),8)。本研究は目下、後者の立場をとるものであるが、 アルゴリズムの妥当性についても適宜検討していきた い。また、土地の利用情報を含めて、より広い地域を 対象とした長時間にわたる汇濫計算を行っていく予定 である。

\section{謝辞}

最後に本研究を実施するにあたり、長岡市土木部(木 本二郎部長)下水道管理課（和田行夫課長、鈴木忠夫技 師）より、柿川に関する種々の資料、およびマンホー ル標高データの資料をお送り頂いた。また、長岡技術 科学大学の山本技官にはデータ入力作業のお手伝いを 頂いた。ここに謝意を表する。

\section{参考文献}

1) 日本地形学連合・技術講習会実行委員会（代表 : 野上道 男）：DEMデータ処理技術講習会テキスト,2000.

2) 酒井彩美·細山田得三-早川典生·福嶋祐介、氾濫流の伝播特 性に関する研究、第18回土木学会関東支部新潟会研究調査 発表会論文集, pp. 57-58, 2000.

3) 粟城稔、末次忠司、海野仁、田中義人、小林裕明、氾濫シ ミュレーション・マニュアル（案） -シミュレーションの 手引き及び新モデルの検証-、土木技術研究所資料、第3400 号、 1996.

4) 土木学会編 : 水理公式集、昭和 46 年改訂版, 1971.

5) 秋山壽一郎、浦勝、重枝末玲、アキレス K.ジャ、1 次元浅 水流方程式のFDSに基づく数值解析法、水工学論文集、第 44 巻, pp.473-478.

6) 川池健司、井上和也 - 戸田圭一 : 非構造格子の都市汇濫解 析一の適用、水工学論文集、第 44 巻、pp.461-466,2000..

7) 武田誠、松尾直規 : 汇濫水に与える下水道システムの影響 に関する数值解析的検討、水工学論文集、第 44 巻、 pp.467-472., 2000.

8) 戸田圭一、井上和也、村瀬賢、市川温、横尾英男 : 豪雨に よる京都市域の汇濫解析、水工学論文集、第 44 巻, pp.479484

(2001. 10.1受付) 